Indonesian Journal of Islamic Communication, Vol. 1, No. 2, Desember 2018: 22-35

\title{
KOMPONEN FILSAFAT DALAM ILMU KOMUNIKASI
}

\author{
Nila Noer Karisna \\ Program Studi Komunikasi dan Penyiaran Islam \\ Institut Agama Islam Negeri Jember
}

Diunggah 30 Oktober / Direvisi 22 November / Diterima 28 Desember 2018

\begin{abstract}
Abstrac: As a social being, it certainly will not be separated from an interaction between one creature and another, commonly referred to as communication. Communication science learns about how to deliver messages from the message maker to the recipient of the message with a specific purpose that causes certain effects. However, in the communication process there is often a misunderstanding in receiving and reviewing the message. So that communication can cause conflict and misinformation can lead to Hoax news. Therefore, today we need to apply the philosophical foundation in communication science, namely through Ontology, Epistemology, and Axiology. With this foundation will create a paradigm of communication that is developing.
\end{abstract}

Keywords; Philosophy, Communication, Ontology, Epistemology, and Axiology

Korespondensi: Nila Noer Karisna

Kd. Ringin Muncar Banyuwangi

nilarisna40@gmail.com 


\section{A. PENDAHULUAN}

Sebagai makhluk sosial tentu tidak akan lepas dari hubungan interaksi antara makhluk satu dengan yang lainnya. Dalam berinteraksi manusia akan menyampaikan pesan kepada manusia lain atau pada diri sendiri. Interaksi yang terjadi pada diri manusia biasa kita sebut dengan istilah komunikasi yaitu proses penyampaian pesan dari seorang komunikator kepada komunikan dengan tujuan dan efek tertentu. Hal ini dapat dihubungkan dengan tujuan dari berkomunikasi yang tidak memandang perbedaan. Seperti firman Allah SWT dalam surat Al-Hujurat ayat 13:

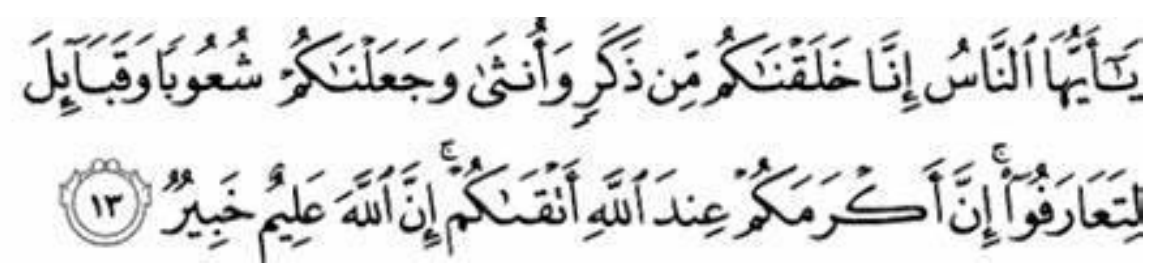

Artinya: Hai manusia, sesungguhnya Kami menciptakan kamu dari seorang laki-laki dan seorang perempuan dan menjadikan kamu berbangsa-bangsa dan bersuku-suku supaya kamu saling kenal-mengenal. Sesungguhnya orang yang paling mulia diantara kamu disisi Allah ialah orang yang paling takwa diantara kamu. Sesungguhnya Allah Maha Mengetahui lagi Maha Mengenal.

Dari ayat tersebut jelas bahwa berkomunikasi dengan sesama makhluk hidup tidak me mandang perbedaan. Pada era globalisasi ini komunikasi dengan sesama makhluk hidup sangatlah mudah dengan semakin berkembangnya teknolongi seperti halnya media yang sedang menjadi acuan masyarakat dalam menjalani kehidupan dan menerima informasi. Akan tetapi dalam menerima informasi pelaku komunikasi harus saling memberikan keuntungan dan timbal balik yang signifikan. Apabila pelaku komunikan atau media dalam menyampaikan pesan kepada komunikan tidak melalui strategi maka akan terjadi ketidak sambungan antara komunikator dengan komunikan sehingga terjadi berita atau kabar yang tidak sesuai dengan realita.

Seiring berkembangnya teknolongi sebagai manusia harus mempunyai prinsip dalam menggunakan media massa agar terhindar dari isu Hoax yang sering terjadi saat ini. Sehingga hal tersebut dapat memicu adanya kesenjangan sosial atau konflik sosial. Oleh sebab itu dengan berfikir lebih mendalam dan lebih luas melalui tiga landasan berfilsafat yaitu ontologi, epistimologi, dan aksiologi maka kita akan menemukan satu titik kebenaran dalam menyampaikan pesan dari seorang komuikator kepada komunikan yang memiliki tujuan dan efek tertentu dan 
komunikan sebagai penerima pesan juga terhindar dari berita bohong yang dapat menimbulkan konflik antarsesama manusia.

\section{B. PEMBAHASAN}

\section{Tiga Landasan Filsafat Komunikasi}

Filsafat sebagai akar ilmu akan diuraikan melalui pilar utama yaitu ontolongi, epistimolongi, dan aksiologi. Ketiga komponen filsafat tersebut sangat menentukan bagi strategi pengembangan ilmu yang dipilih termasuk pengembangan ilmu komunikasi. ${ }^{1}$

Menurut Withney R. Mundt filsafat komunikasi menampilkan kekuatan media dan prinsip fungsi media serta berhubungan dengan Negara. Mundt dalam penjelasannya keterpantauan pemerintah dengan jurnalistik sehingga keseimbangan kekuatan selalu bergeser. ${ }^{2}$

Menurut Mundt, pers terbagi menjadi lima yakni:

a) Otoriter, yakni sistem pers ada sesnsor dan lisensi dari pemerintah. Pemerintah menekan kritik sehingga kekuasaan terpelihara.

b) Sosial-otoriter, yakni pers dimiliki oleh pemerintah atau partai pemerintah untuk melengkapi pers guna mencapai tujuan ekonomi nasional dan tujuan filsafati.

c) Libertarian, yakni ketiadaan pengawasan pemerintah (kecuali undang-undang tentang fitnah dan cabul), untuk menjamin perkembangannya gagasan secara bebas (free market of ideas).

d) Sosial-libertarian, yakni pengawasan pemerintah secara minimal untuk menyumbat saluran-saluran komunikasi dan untuk menjamin semangat operasional dari filsafat libertarian.

e) Sosial-sentralis, yakni kepemilikan pemerintah atau lembaga umum dengan saluran komunikasi terbatas untuk menjamin semangat operasional dari filsafat libertarian. ${ }^{3}$

Proses komunikasi dapat dilihat dari dua perspektif yaitu psikologis dan mekanis. Perspektif psikologis menjelaskan bahwa komunikasi adalah aktivitas psikologi sosial yang melibatkan komunikator , komunikan , isi pesan , lambang,

\footnotetext{
${ }^{1}$ Winangsih nina, Rekonstruksi Ilmu Komunikasi Perspektif Pohon Komunikasi dan pergeseran paradigma Komunikasi Pembangunan Dalam Era Globalisasi, ( Bandung: Penerbit ITB, 2002),19.

2 Muhammad mufid, Etika dan Filsafat Komunikasi (Jakarta: Prenadamedia Group, 2009),96.

3 Ibid, 97.
} 
sifat hubungan, persepsi, proses mengkode dan dikode. sedangkan perspektif mekanis menjelaskan bahwa komunikasi merupakan aktivitas mekanik yang dilakukan oleh komunikator dan bersifat situasional serta kontekstual. 4

Dari proses komunikasi yang begitu kompleks dan tidak sederhana tersebut, refleksi komunikasi diperlukan untuk mendapatkan prespektif yang lebih luas dan komprehensif. Refleksi proses komunikasi tersebut sering dimasukkan dalam disiplin filsafat komunikasi. Pemikiran filsafat selalu menyatu dengan pemikiran teori komunikasi. Ada beberapa tokoh pemikir filsafat komunikasi. Yaitu:

\section{Ontologi}

Richard secara khusus membahas analisis filosofis atau proses komunikasi. Filsafat bertitik refleksi pada pertanyaan-pertanyaan. Yaitu:

- Pertanyaan masalah ontologi atau metafisika

- Pertanyaan masalah epistemology

- Pertanyaan masalah aksiologi

- Pertanyaan masalah logika

Richard menjelaskan bahwa ontologi atau metafisika merupakan studi tentang sifat dan fungsi teori dalam sebuah realitas. Ada beberapa hal yang direfleksikan dengan dalam metafisika yaitu sifat manusia dan hubungannya dengan alam, sifat dan fakta kehidupan manusia, problema pilihan manusia, dan soal kebebasan pilihan tindakan manusia. Berhubungan dengan teori komunikasi, ontologi atau metafisika berkaitan dengan beberapa hal berikut:

- Sifat manusia dan hubungannya secara kontestual dan indivisual dengan realita dalam alam semesta.

- Problema pilihan, khususnya kebebasan versus determinisme pada perilaku manusia. ${ }^{5}$

Ontologi membicarakan tentang hakikat dan struktur sain. Hakikat sain menjelaskan apa itu sain sebenarnya. 6 Sain atau ilmu dapat dilihat dari objek material dan formal. Untuk komunikasi dikelompokkan pada ilmu sosial dan merupakan ilmu terapan. Para ahhli menganggap demikian karena ilmu

\footnotetext{
${ }^{4}$ Ibid,83.

5 (Ibid),85.

${ }^{6}$ Tafsir ahmad, Filsafat Ilmu,(Bandung: PT Remaja Rosdakarya,2004)
} 
komunikasi sifatnya interdisipliner atau multidisipliner hal ini disebabkan oleh objek materialnya sama dengan ilmu-ilmu lainnya terutama yang termasuk dalam ilmu ilmu sosial atau ilmu kemasyarakatan. ${ }^{7}$

Brooks menjelaskan bahwa ilmu komunikasi merupakan integrasi prinsip-prinsip komunikasi yang diketengahkan para cendikiawan berbagai disiplin akademik. Komunikasi juga suatu filsafat komunikasi yang realistis, suatu progam penelitian yang sistematis yang mengkaji teori-teorinya, menjembatani kesenjangan dalam pengetahuan, memberikan penafsiran, dan saling mengabsahkan penemuan-penemuan yang dihasilkan disiplin-disiplin khusus dan progam-progam penelitian. ${ }^{8}$

Menurut pemikiran Stephen W. Littlejohn ontology memiliki fungsi positif perspektif dapat menyusun teori-teori komunikasi sehingga memudahkan didalam penggunaan teori-teori nkomunikasi sesuai dengan fokus dan landasan pikiran. ${ }^{9}$

Membahas ilmu komunikasi tentu tidak akan lepas dari pertanyaan tentang apa sebenarnya ilmu komunikasi itu, apa yang dibahas didalam ilmu komunikasi, objek apa yang masuk dalam kajian ilmu komunikasi.

Dalam aspek ontologi,misalnya: ilmu komunikasi massa berfokus pada berita yang mempengaruhi minat masyarakat untuk mengetahui berita tersebut. Ilmu komunikasi antarpribadi berfokus pada pesan yang akan disampaikan pada orang lain, apakah pesan tersebut dapat memberikan efek yang sesuai dengan tujuan atau tidak, dll.

Dari banyaknya fenomena komunikasi masaa yang baru-baru ini menjadi topic hangat adalah adanya berita hoax yang beredar begitu pesat salah satunya tentang isu penganiayaan yang dialami oleh Ratna sarumpaet dengan cepat menyebar dimedia sosial dan mendapat banyak tanggapan dari berbagai netizen.

Berbeda dengan dalam kajian filsafati pada ilmu komunikasi yang ditulis oleh Rachmat Kriyantono menyatakan bahwa Actional Theory atau Rules Theory individu menciptakan makna, mempunyai maksud dan

\footnotetext{
${ }^{7}$ Uchjana Onong Effendy, Ilmu Komunikasi Teori dan Praktek,(Bandung: PT Remaja Rosdakarya, 1990$), 3$.

8 Ibid, 5.

${ }_{9}$ Muhammad mufid, Etika dan Filsafat Komunikasi (Jakarta: Prenadamedia Group, 2009),95.
} 
mempunyai atau menentukan pilihan nyata. orang-orang berperilaku berbeda dalam situasi berbeda karena aturan berubah dari satu situasi ke situasi lainnya. Perilaku manusia merupakan hasil atau akibat dari pilihan bebas. Nonactional Theory atau Covering Laws Perilaku pada dasarnya ditentukan oleh dan respon pada biologi dan lingkungan. "Covering Laws" biasanya dipandang cocok untuk tradisi ini; interpretasi aktif oleh individu tidak dianggap. Ada relasi yang terpadu antara dua atau lebih objek. Contoh: ketika A terjadi maka B terjadi. Ini adalah pernyataan sebab-akibat yang menjelaskan hubungan antara A dan B. Disebut juga teori-teori yang fokus pada sebabakibat (causal necessity). Proses komunikasi, dengan demikian, dipahami sebagai proses sebab-akibat, ada peristiwa yang didahului peristiwa lainnya. System Theory Teori-teori sistem menegaskan bahwa perilaku manusia, termasuk proses komunikasi, merupakan bagian dari sebuah system. Contoh: keluarga adalah system dari relasi keluarga, lebih dari sekedar anggota-anggota secara individual. Pernyataan ini menjelaskan kompleksitas polapola komunikasi dalam keluarga. Fokus pada hubungan logis antara komponenkomponen system yang memiliki baik causal ataupun practical necessity dan merupakan pendekatan teoritis yang paling umum. ${ }^{10}$

\section{Epistemologi}

Epistemologi merupakan cabang filsafat yang menyelidiki asal, sifat, metode, dan gagasanpengetahuan manusia. Epistemolongi pada dasarnya adalah cara bagaimana pengetahuan disusun dari bahan yang diperoleh dengan menggunakan metode ilmiah, yaitu suatu kegiatan berdasarkan perencanaan yang matang dan mapan, sistematik, dan logis. Rumusan lain, epistemologi adalah cabang filsafat yang mempelajari watak, batas-batas, dan berlakunya ilmu pengetahuan. ${ }^{11}$

Epistemology pada dasarnya adalah cara bagaimana pengetahuan disusun dari bahan yang diperoleh yang dalam prosesnya menggunakan metode ilmiyah. ${ }^{12}$

\footnotetext{
${ }^{10}$ http://rachmatkriyantono.lecture.ub.ac.id/files/2014/10/2.-Kajian-Filsafati-pada-Ilmu-Komunikasibaru.pdf

${ }^{11}$ Winangsih nina, Rekonstruksi Ilmu Komunikasi Perspektif Pohon Komunikasi dan pergeseran paradigma Komunikasi Pembangunan Dalam Era Globalisasi, ( Bandung: Penerbit ITB, 2002),21.

${ }^{12}$ Muhammad mufid, Etika dan Filsafat Komunikasi (Jakarta: Prenadamedia Group, 2009$), 87$.
} 
Lagian menjelaskan bahwa prosesnya yang progesif dari kognisi yang menuju konasi, epistemology berpijak pada salah satu atau lebih teori kebenaran. ${ }^{13}$

Sedangkan menurut pemikitan Stephen W. Littlejohn epistemology merupakan cabang filsafat yang mempelajari pengetahuan apa yang diklaim sebagai pengetahuan. Karena keanekaragaman yang disiplin yang ada dalam study komunikasi dan perbedaan pemikiran, mmaka isu-isu epistemology menjadi penting. Landasan pemikiran dala komunikasi dapat dibedakan melalui standar epistemiologi teori-teori komunikasi berpusat pada paradigma positivisme akan berberda dengan landasan kritis dan konstruktivis. ${ }^{14}$

Objek kajian sain haruslah objek-objek yang empiris sebab bukti-bukti yang harus ia temukan adalah bukti-bukti yang empiris. Bukti empiris ini diperlukan untuk menguji bukti rasional yang telah dirumuskan dalam hipotesis. ${ }^{15}$

Dalam kajian epistemologi, ilmu komunikasi dititikberatkan pada berita atau kabar yang sesuai dengan bukti atau fakta untuk menjadikan berita tersebut bernilai tinggi dan berkualitas. Sehingga pesan yang ditujukan kepada masyarakat bersifat umum atau tidak memihak hal tersebut dapat dibuktikan melalui metode dari ketepatan waktu dalam memberikan informasi, akurat, seimbang, jelas, dan padat terpercaya.

Dengan cara mengkaji epistemologi wartawan atau komunikator dalam menyampaikan pesan kepada audiens atau komunikan sudah mendekati akurat. Masyarakat juga tidak akan ragu dalam menerima pesan yang disampaikan oleh media tersebut. Seperti berita yang datang dari Ratna Sarumpaet yang menyebar berita bohong bahwa telah dianiaya oleh oknum tertentu dimedia sosial yang dengan cepat menyebar luas dengan cepat sehingga dengan mudah masyarakat menerima berita tersebut bahkan sampai menerima simpati dari banyak netizen, akan tetapi apabila komunikan atau netizen yang menerima berita tersebut dapat menguji keakuratan dan

\footnotetext{
13 Ibid, 87.

14 Ibid,93.

15 Tafsir ahmad, Filsafat Ilmu,(Bandung: PT Remaja Rosdakarya,2004)
} 
keaktualan berita tersebut maka berita hoax tidak akan mudah diterima secara mudah. Epistemology dianggap sangat penting dalam menyaring dan menerima pesan dimedia sosil khususnya berita hoax yang dapat terjadi dan menyebar kapan saja.

Pengertian epistemology komunikasi dalam kajian Rachmat Kriyantono menyatakan bahwa :

a) Apakah pengetahuan karena pengalaman? Beberapa ilmuwan percaya bahwa semua pengetahuan muncul dari pengalaman. Kita mengobservasi dunia dan karena itu mengenalnya. Apakah ada sesuatu dalam diri kita yang menyediakan tipe pengetahuan tertentu walau kita belum mengalaminya? Tipe "pengetahuan" ini muncul dari mekanisme berpikir yang inheren dalam diri dan persepsi. Contoh: bukti kuat menyatakan bahwa anak-anak tidak belajar bahasa secara keseluruhan dari kegiatan mendengarkan orang bicara. Tetapi, anak-anak membangun bahasa dengan cara menggunakan "innate models" (bawaan lahir) untuk mengetest apa yang mereka dengar.

b) Apakah pengetahuan dapat dianggap pasti? Apakah pengetahuan pasti? Atau apakah pengetahuan bersifat relatif dan berubah? Beberapa teoritisi yang mempunyai pendirian atau sikap universal akan mengakui kesalahankesalahan dalam teori-teori mereka. Tetapi mereka percaya bahwa kesalahan (errors) tersebut hanya sebuah hasil dari kebenaran yang lengkap yang belum terungkap. Para relativist akan meminta kita untuk percaya bahwa pengetahuan tidak akan pernah pasti karena "realitas universal itu tidak ada".

c) Melalui proses apa pengetahuan dibangun? Mentalisme (rationalisme): pengetahuan timbul dari kekuatan pikiran manusia. Posisi ini menempatkan kepercayaan fundamental (ultimate faith) pada penalaran manusia. Empirisme: menyatakan bahwa pengetahuan timbul dalam persepsi kita saat mengalami dunia dan melihat apa yang sedang terjadi. Konstruktivisme: menyatakan bahwa orang-orang menciptakan pengetahuan agar berfungsi pragmatis dalam kehidupan. Orang memproyeksikan dirinya kepada apa yang dialaminya. Kaum konstruktivis percaya bahwa fenomena dalam dunia dapat dikonseptualisasikan ke 
dalam berbagai cara, pengetahuan menjadi sesuatu yg berperan penting bagi seseorang untuk merekayasa dunia. Konstruktivisme sosial: menyatakan bahwa pengetahuan adalah produk dari interaksi simbolik dalam kelompokkelompok sosial. Dengan kata lain, realitas adalah sesuatu yang dikonstruksi secara sosial dan merupakan produk kehidupan kelompok dan budaya.

d) Apakah pengetahuan sebaiknya dipahami sebagian atau sebagai keseluruhan? Para kaum holistik menyatakan bahwa pengetahuan sangat berhubungan dan bekerja sebagai sebuah sistem, dibuat dari generalitas dan pemahaman yang tidak dapat dibagi-bagi. Kaum Analis percaya bahwa pengetahuan muncul dari pemahaman tentang bagaimana bagianbagian beroperasi secara terpisah. Mereka tertarik dalam memisahkan, mengkategorikan dan menganalisis komponen-komponen yang berbeda yang bersama-sama membentuk pengetahuan.

e) Sejauh mana pengetahuan bersifat eksplisit? Beberapa filosof percaya bahwa kita tidak dapat mengetahui sesuatu kecuali kita menyatakannya dengan jelas. Pengetahuan dengan demikian dilihat sebagai sesuatu yang eksplisit. Beberapa yang lain mengklaim bahwa pengetahuan adalah tersembunyi, bahwa orangorang mengoperasikan pengetahuan pada sensibilitas dasar yang tidak disadari dan mereka mungkin tidak dapat mengeskpresikannya. Pengetahuan yg demikian dikatakan sebagai tacit (bawah sadar). ${ }^{16}$

\section{Aksiologi}

Aksiologi bidang utama filsafat ketiga yang mmembahas tentang masalah nilai. Istilah aksiologi berasal dari kata yunani "Axios" dan "Logos". Axios artinya nilai atau sesuatu yang berharga, Logos artinya teori atau akal. Aksiologi berarti teori nilai, penyelidikan mengenai kodrat, kriteria, dan status metafisika dari nila-nilai dalam pemikiran filsafat yunani. ${ }^{17}$

Dalam hubungan filsafat komunikasi Laginan menjelaskan bahwa aksiologi merupakan study etika dan estetika. Hal ini berkaitan dengan betapa

\footnotetext{
${ }^{16}$ http://rachmatkriyantono.lecture.ub.ac.id/files/2014/10/2.-Kajian-Filsafati-pada-Ilmu-Komunikasibaru.pdf

17 Winangsih nina, Rekonstruksi Ilmu Komunikasi Perspektif Pohon Komunikasi dan pergeseran paradigma Komunikasi Pembangunan Dalam Era Globalisasi, ( Bandung: Penerbit ITB, 2002),21.
} 
pentingnya seseorang komunikator dalam mengemas pemikirannya menjadi suatu isi pesan dengan bahasa sebagai lambang, untuk terlebih dahulu melakukan pertimbangan nilai apakah pesan itu etis atau tidak dan estetis atau tidak. $^{18}$

Pada bagian ini dibicarakan tiga hal saja, pertama kegunaan ilmu, kedua, cara ilmu, menyelesaian masalah, ketiga, netralitas pengetahuan. ${ }^{19}$

Ilmu komunikasi jika dipandang secara aksiologi berfokus pada fungsi komunikasi. Apabila komunikasi massa maka yang dilihat dari fungsi media yaitu hiburan, informasi, mempengaruhi, dan mendidik. Sehingga para praktisi media harus memiliki kemampuan untuk membuat ide agar bisa menarik para komunikan atau audiens dalam menerima pesan yang akan disampaikan oleh media tersebut.

Membahas tentang berita hoax Ratna Sarumpaet jika ditelaah dengan aksiologi maka pemeritaan yang telah dibuat merupakan sesuatu yang tidak mmemiliki manfaat bagi komunikan. Karena dengan menyebarkan berita hoax maka sama halnya dengan membohongi banyak pihak. Dan aka nada beberapa pihak yang merasa dirugikan dengan penyebaran berita hoax tersebut. Sehingga sangat perlu untuk komunikan menyaring sebuah pesan dalam menerima berita yang tersebar dimedia sosial.

Berbeda dengan kajian filsafat komunikasi milik Rachmat Kriyantono menjelaskan bahwa:

1) Apakah ilmu bebas nilai? Ilmuwan klasik menganggap bahwa teori-teori dan riset adalah bebas nilai, ilmu pengetahuan bersifat netral, berupaya mendapat fakta sebagaimana tampak dalam dunia nyata. Jika pandangan pribadi ilmuwan tercampur, maka menghasilkan ilmu yg bias. Posisi lain dalam isu ini adalah ilmu pengetahuan adalah tidak bebas nilai.

2) Apakah proses penelitian memengaruhi apa yang diteliti? Kaum tradisional menganggap penelitian harus dilakukan tanpa campur tangan peneliti sehingga dapat akurat. Tetapi, muncul kritik bahwa tidak ada metode yang benar-benar bebas dari distorsi. Contoh: metode eksperimen selalu

${ }^{18}$ Muhammad mufid, Etika dan Filsafat Komunikasi (Jakarta: Prenadamedia Group, 2009),88.

19 Tafsir ahmad, Filsafat Ilmu,(Bandung: PT Remaja Rosdakarya,2004) 
memengaruhi bagaimana partisipan bereaksi yang berbeda dalam reaksi keseharian mereka.

3) Apakah penelitian dirancang untuk menuju perubahan sosial atau hanya untuk membangun pengetahuan? Para ilmuwan tradisional menyatakan bahwa mereka tidak bertanggung jawab terhadap caracara penggunaan pengetahuan ilmiah. Sementara yang lain menganggap bahwa pengetahuan ilmiah sangat bersifat instrumentalis atau mempunyai tujuan. Pengetahuan dapat dikendalikan dan menguatkan penyusunan kekuatan dan kuasa di masyarakat. Karena itu ilmuwan bertanggung jawab membantu perubahan di masyarakat. ${ }^{20}$

\section{Paradigma Filsafat Ilmu komunikasi}

Paradigma lama komunikasi ini dibangun atas dasar premis-premis berikut:

1. Komunikasi pembangunan dipandang sebagai penyampaian informasi searah dari pengirim kepada penerima

2. Kebijakan operasional komunikasi pembangunan dibuat secara terpusat.

3. Media massa merupakan komponen pokok dalam menggerakkan pembangunan kepada masyarakat sebanyak mungkin.

4. Modernisasi dipandang sebagai proses difusi informasi dimana masyarakat meninggalkan nilai-nilai tradisional dan mengadopsi nilai-nilai modern (barat) agar memiliki pola hidup modern.

5. Kebutuhan aspirasi pembuat kebijakan dan usahawan sangat diperhatikan dalam pembuatan kebijakan pembangunan.

Paradigma kontemporer banyak diadopsi oleh para pengambil keputusan diberbagai negara dalam membuat kebijakan bidang informasi. Menurut Hogan hal tersebut terjadi karena tumbuhnya kesadaran yang dalam tentang hakikat komunikasi yang mesti menempatkan komunikasi masyarakat sebbagai sentrum, adanya pengertian baru bahwa komunikasi pembangunan harus bertimbal balik, (information excange), adanya trend ke arah demokrasi parsitipatif, kemajuan teknologi dan globalisasi yang membuat informasi berlimpah sehingga akses informasi bagi masyarakat sangat terbuka, adanya kesadaran pentingnya

${ }^{20}$ http://rachmatkriyantono.lecture.ub.ac.id/files/2014/10/2.-Kajian-Filsafati-pada-Ilmu-Komunikasibaru.pdf 
menerapkan sistem komunikasi pembangunan yang terpadu baik dari segi isi pesan, media, teknik komunikasi yang diterapkan, sumber pesan dan perancangan kebutuhan masyarakat.

Paradigma baru dalam materi dan isi pesan informasi yang efektif mengacu pada tingkat relevansi dengan karakteristik kebutuhan masing-masing daerah. Dalam arti faktor etnis, potensi wilayah dan hambatan yang dimiliki setiap daerahakan mempengaruhi isi atau materi yang diperlukan masyarakat setempat. $^{21}$

Dalam kajian Rachmat Kriyantono paradigma filsafat komunikasi yaitu:

a. Positif/Objektif: Ada realitas yang nyata yang diatur oleh kaidahkaidah tertentu yang berlaku universal, walaupun kebenaran pengetahuan tentang itu mungkin hanya dapat diperoleh secara probabilistik. Realitas dianggap berada di luar dunia subjektif ilmuwan Dapat diukur dengan standard tertentu, digeneralisasi dan bebas dari konteks dan waktu. Pandangan ini disebut realisme.

b. Subjektif - Konstruktivis: Realitas merupakan konstruksi sosial. Kebenaran suatu realitas bersifat relative, berlaku sesuai konteks spesifik yang dinilai relevan oleh pelaku sosial, Realitas adalah hasil konstruksi mental dari individu pelaku sosial sehingga realitas dipahami secara beragam dan dipengaruhi oleh pengalaman, konteks dan waktu

c.Subjektif-Kritis: Realitas yang teramati (virtual reality) merupakan realitas semu yang telah terbentuk oleh proses sejarah dan kekuatan-kekuatan sosial, budaya, dan ekonomi politik. ${ }^{2}$

d. Positif/Objektif Ada realitas objektif sebagai suatu realitas yang eksternal di luar diri ilmuwan. Ilmuwan harus sejauh mungkin membuat jarak dengan objek penelitian. Jangan ada penilaian yang subjektif atau bias pribadi. Disebut dualist-objektivist

e.Subjektif-Konstruktif Pemahaman terhadap suatu realitas atau temuan penelitian merupakan produk interaksi antara peneliti dengan yang diteliti Ilmuwan dan objek atau realitas yang diteliti merupakan kesatuan yang tidak terpisahkan Disebut transaktionalist.

\footnotetext{
${ }^{21}$ Winangsih nina, Rekonstruksi Ilmu Komunikasi Perspektif Pohon Komunikasi dan pergeseran paradigma Komunikasi Pembangunan Dalam Era Globalisasi, ( Bandung: Penerbit ITB, 2002),64.

${ }^{22} \mathrm{http}: / /$ rachmatkriyantono.lecture.ub.ac.id/files/2014/10/2.-Kajian-Filsafati-pada-Ilmu-Komunikasibaru.pdf
} 
f. Subjektif-Kritis Hubungan antara peneliti dengan realitas yang diteliti selalu dijembatani oleh nilainilai tertentu. Pemahaman tentang suatu realitas merupakan value-mediated findings. ${ }^{23}$

g.Positif/Objektif: Nilai, etika, dan pilihan moral harus berada di luar penelitian, Peneliti berperan sebagai disinterested scientist , Tujuannya untuk eksplanasi, prediksi dan control realitas.

h. Subjektif-Konstruktif: Nilai, etika, dan pilihan moral merupakan bagian takterpisahkan dari suatu penelitian Peneliti sebagai passionate-participant, fasilitator, yang menjembatani keragaman subjektivitas pelaku sosial Tujuannya untuk rekonstruksi realitas sosial secara dialektis antara peneliti dengan pelaku sosial yang diteliti.

Subjektif-Kritis: Nilai, etika, dan pilihan moral merupakan bagian takterpisahkan dari penelitian Peneliti menempatkan diri sebagai intektual transformasi, advokat daan aktivis Tujuannya untuk kritik sosial, transformasi, emansipasi dan social empowerment. ${ }^{24}$

\section{KESIMPULAN}

Tiga landasan filsafat yang harus dijadikan pedoman dalam menelaah dan mengkaji suatu ilmu sangat penting dilakukan. Dengan cara ontologi maka dapat mengetaui apa sebenarnya ilmu itu dan mengetahui hakikat dari ilmu dengan melihat dari obyek material dan formal. Komunikasi jika dikaji dengan ontologi maka akan menemukan hakikat komunikasi yang sebenarnya. Misalnya khusus komunikasi massa jika dikaji dengan ontologi maka akan menemukan apa yang menjadi obyek dari komunikator atau praktisi media.

Dengan menkaji komunikasi menggunakan epistimologi kita dapat mengetahui tentang bagaimana ilmu disusun. Epistemologi juga memberikan cara agar manusia lebih selektif dalam menerima pesan komunikasi.

Setelah mengkaji menggunakan epistemologi dan yang terakhir komunikasi dapat dikaji dengan aksiologi atau kegunaan dari ilmu komunikasi khusunya komunikasi massa maka akan ada tindakan dalam memahami pesan dan mengkaji ulang pesan agar tidak terjadinya kesalah fahaman dalam proses komunikasi. Dengan aksiologi

${ }^{23}$ Ibid.

24 Ibid. 
dapat diketahui beberapa fungsi dari komunikasi yaitu sebagai sarana informasi, hiburan, pendidikan, dan pengaruh.

Ilmu komunikasi yang sudah dikaji melalui tiga landasan akan menghasilkan paradigma-paradigma baru dalam perkembangan komunikasi di era globalisasi yang serba canggih.

\section{DAFTAR PUSTAKA}

Tafsir ahmad, Filsafat Ilmu,(Bandung: PT Remaja Rosdakarya,2004)

Uchjana Onong Effendy, Ilmu Komunikasi Teori dan Praktek,(Bandung: PT Remaja Rosdakarya, 1990)

Winangsih nina, Rekonstruksi Ilmu Komunikasi Perspektif Pohon Komunikasi dan pergeseran paradigma Komunikasi Pembangunan Dalam Era Globalisasi, ( Bandung: Penerbit ITB, 2002)

Muhammad mufid, Etika dan Filsafat Komunikasi (Jakarta: Prenadamedia Group, 2009)

http://rachmatkriyantono.lecture.ub.ac.id/files/2014/10/2.-Kajian-Filsafati-padaIlmu-Komunikasi-baru.pdf 